\title{
Hydrogen Peroxide is Involved in the Regulation of Ascorbate and Glutathione Metabolism in Wheat Leaves under Water Stress
}

\author{
C. SHAN ${ }^{1,2 *}$ and $\mathrm{X} \cdot \mathrm{OU}^{1,2}$ \\ ${ }^{1}$ School of Science and Technology, Henan Institute of Science and Technology, Xinxiang, 453003 China \\ ${ }^{2}$ Collaborative Innovation Center of Modern Biological Breeding, Henan Province, Xinxiang, 453003 China
}

(Received 29 January 2017; Accepted 17 May 2017;

Communicated by A. Pécsváradi)

This study investigated the regulation of ascorbic acid and glutathione metabolism by hydrogen peroxide in wheat leaves under water stress. The results showed that $\mathrm{H}_{2} \mathrm{O}_{2}$ level, the activities of ascorbate peroxidase, glutathione reductase, monodehydroascorbate reductase, dehydroascorbate reductase, L-galactono-1,4-lactone dehydrogenase and gamma-glutamylcysteine synthetase, and the contents of reduced ascorbate, reduced glutathione, total ascorbate and total glutathione were increased by water stress. And above increases were suppressed by pre-treatment with NADPH oxidase inhibitor diphenyleneiodonium chloride. Application of DPI also reduced $\mathrm{H}_{2} \mathrm{O}_{2}$ level, the activities of $\gamma$-ECS, GalLDH, APX, GR, DHAR and MDHAR, and the contents of AsA, GSH, total ascorbate and total glutathione, compared with control. Application of $\mathrm{H}_{2} \mathrm{O}_{2}$ to DPI-inhibited wheat seedlings prevented the reduction in the activities of APX, GR, MDHAR, DHAR, GalLDH and $\gamma$-ECS, and the contents of AsA, GSH, total ascorbate and total glutathione induced by DPI under water stress. Meanwhile, pre-treatment with DPI increased the malondialdehyde content and electrolyte leakage. Application of $\mathrm{H}_{2} \mathrm{O}_{2}$ to DPI-inhibited wheat seedlings prevented the increases in MDA content and EL. Our results suggested that water stress-induced $\mathrm{H}_{2} \mathrm{O}_{2}$ is a signal that leads to the up-regulation of ascorbate and glutathione metabolism and has an important role for acquisition of water-stress tolerance in wheat.

Keywords: water stress, hydrogen peroxide, ascorbate, glutathione, wheat

Abbreviations: APX - ascorbate peroxidase; DHAR - dehydroascorbate reductase; DPI - diphenyleneiodonium chloride; EL - electrolyte leakage; $\gamma$-ECS - gamma-glutamylcysteine synthetase; GR - glutathione reductase; $\mathrm{H}_{2} \mathrm{O}_{2}$ - hydrogen peroxide; GalLDH L-galactono-1,4-lactone dehydrogenase; MDA - malondialdehyde; MDHAR - monodehydroascorbate reductase; AsA - reduced ascorbate; GSH - reduced glutathione

\section{Introduction}

Water stress adversely affects plant growth, productivity and survival. Water stress usually induces the accumulation of reactive oxygen species (ROS), which cause oxidative damage to plants (Ansari et al. 2016; Mohammadi and Moradi 2016). Plants could protect

*Corresponding author. E-mail: shchjuan1978@aliyun.com 
themselves against oxidative damage by antioxidative enzymes such as catalase (CAT) and superoxide dismutase (SOD), and nonenzymatic compounds such as ascorbate and glutathione (Sang et al. 2016).

Ascorbate and glutathione are two crucial nonenzymatic compounds involved in defence against oxidative stress. Plants can adjust the contents of ascorbate and glutathione by modulating their regeneration and biosynthesis. GalLDH is the key enzyme in the main biosynthetic pathway of ascorbate (Wheeler et al. 1998). $\gamma$-ECS is the key enzyme for glutathione biosynthesis (Dringen 2000). Ascorbate-glutathione (AsA-GSH) cycle is the recycling pathway of ascorbate and glutathione. Thus, the ascorbate-glutathione cycle plays an important role in maintaining the contents of ascorbate and glutathione in plants. In this cycle, APX, MDHAR, DHAR and GR are the key enzymes (Singh et al. 2015).

Hydrogen peroxide $\left(\mathrm{H}_{2} \mathrm{O}_{2}\right)$ is a key signal molecule in plants. Evidences have shown that $\mathrm{H}_{2} \mathrm{O}_{2}$ is a key regulator in response to stresses (Wu et al. 2015; Mostofa et al. 2015). It has been documented that $\mathrm{H}_{2} \mathrm{O}_{2}$ could regulate the contents of ascorbate and glutathione through APX and GR in AsA-GSH cycle in maize leaves under water and heat stress (Zhang et al. 2007; Wang et al. 2014). However, whether $\mathrm{H}_{2} \mathrm{O}_{2}$ regulates DHAR and MDHAR in AsA-GSH cycle and key biosynthetic enzymes for ascorbate and glutathione (GalLDH and $\gamma$-ECS) under water stress remains unknown.

Wheat is an important crop for human. However, it always encounters drought stress, which seriously inhibits its growth and development. In our previous observation, a cultivar of winter wheat named Bainong 207 showed a better antioxidant ability indicated by higher contents of ascorbate and glutathione under water stress. However, the signal role of $\mathrm{H}_{2} \mathrm{O}_{2}$ in the regulation of the contents of ascorbate and glutathione in wheat under water stress is still unclear. So, investigating the signal role of $\mathrm{H}_{2} \mathrm{O}_{2}$ in the regulation of ascorbate and glutathione metabolism is important to elucidate the antioxidant mechanism of wheat under water stress.

In this study, we investigated $\mathrm{H}_{2} \mathrm{O}_{2}$ levels, the activities of enzymes in ascorbate and glutathione metabolism, and the contents of AsA, GSH, total ascorbate and total glutathione in Bainong 207 leaves exposed to water stress induced by 10\% PEG-6000. The aim of this study was to elucidate whether $\mathrm{H}_{2} \mathrm{O}_{2}$ regulates the ascorbate and glutathione metabolism of Bainong 207 under water stress, and provide new knowledge to the antioxidant metabolism in wheat crop under water stress.

\section{Materials and Methods}

\section{Plant material, growth conditions and treatments}

Seeds of wheat cultivar Bainong 207 were germinated and grown in distilled water in the artificial climate chamber under a temperature of $25 / 15^{\circ} \mathrm{C}$ (day/night), $500 \mu \mathrm{mol} \mathrm{m} \mathrm{m}^{-2} \mathrm{~s}^{-1}$ photosynthetic active radiation and a $12-\mathrm{h}$ photoperiod. When the first leaf was fully expanded, the roots of seedlings were placed in plastic boxes filled with half-strength Hoagland's solution and kept the roots in dark. The nutrition solution was exchanged 
every two days. When the third leaf was fully expanded. The seedlings with similar growth condition were selected for experiments.

In each treatment, we treated the seedlings by placing their roots in corresponding solutions and determined the physiological and biochemical indexes in leaves. To study the effect of water stress, the roots of one group of seedlings were placed in beakers containing $50 \mathrm{ml} 10 \%$ (W/V) PEG solution for $48 \mathrm{~h}$. The osmotic pressure of the used PEG-6000 solution is $-0.2 \mathrm{MPa}$. To study the effect of NADPH oxidase inhibitor diphenyleneiodonium chloride (DPI), the roots of one group of seedlings were pretreated by $80 \mu \mathrm{M}$ DPI for $12 \mathrm{~h}$ and then exposed to water stress for $48 \mathrm{~h}$. A $80 \mu \mathrm{M}$ DPI was selected from a series of DPI concentrations $(20,40,80$ and $120 \mu \mathrm{M})$. To study if the effect of DPI can be reversed by exogenous $\mathrm{H}_{2} \mathrm{O}_{2}$, the roots of seedlings were pre-treated by $30 \mu \mathrm{M} \mathrm{H}_{2} \mathrm{O}_{2}+80 \mu \mathrm{M}$ DPI for $12 \mathrm{~h}$ and then exposed to water stress for $48 \mathrm{~h}$. There is no direct chemical reaction between $\mathrm{H}_{2} \mathrm{O}_{2}$ and DPI (Andriunas et al. 2012). A $30 \mu \mathrm{M} \mathrm{H}_{2} \mathrm{O}_{2}$ was selected from a series of $\mathrm{H}_{2} \mathrm{O}_{2}$ concentrations $(10,30,60,90$ and $120 \mu \mathrm{M})$. The roots of control seedlings were treated by distilled water alone. After treatment of 24 and $48 \mathrm{~h}$, the third leaves were collected and frozen in liquid nitrogen, and then kept at $-80{ }^{\circ} \mathrm{C}$ until used analyses.

\section{Analysis of APX, GR, DHAR, MDHAR}

Enzymes were extracted according to Grace and Logan (1996). Ascorbate peroxidase (APX, EC 1.11.1.11) activity was measured by monitoring the decrease in absorbance at $290 \mathrm{~nm}$ (Nakano and Asada 1981). One unit of enzyme was defined as the amount of APX catalyzing the oxidation of $1 \mu \mathrm{mol}$ ascorbate per minute. Glutathione reductase (GR, EC 1.6.4.2) activity was monitored at $340 \mathrm{~nm}$ (Miyake and Asada 1992). One unit of GR activity was defined as the oxidation of $1 \mu \mathrm{mol}$ NADPH per minute. Monodehydroascorbate reductase (MDHAR, EC 1.6.5.4) activity was assayed at $340 \mathrm{~nm}$ (Miyake and Asada 1992). One unit of MDHAR activity was defined as the amount of enzyme that oxidizes $1 \mu \mathrm{mol}$ NADH per minute. Dehydroascorbate reductase (DHAR, EC 1.8.5.1) activity was measured at $265 \mathrm{~nm}$ (Dalton et al. 1986). One unit of DHAR activity was defined as the amount of enzyme that produces $1 \mu \mathrm{mol}$ AsA per minute. The specific enzyme activity for above enzymes was expressed as units $\mathrm{mg}^{-1}$ protein.

\section{Analysis of GalLDH and $\gamma$-ECS}

L-galactono-1,4-lactone dehydrogenase (GalLDH, EC 1.3.2.3) was extracted and measured by the method of Tabata et al. (2001). One unit of activity is defined as the amount of extract required to oxidize $1 \mathrm{nmol}$ of L-Gal per minute. Gamma-glutamylcysteine synthetase ( $\gamma$-ECS, EC 6.3.2.2) was extracted and measured by the method of Rüegsegger and Brunold (1992). The specific enzyme activities were expressed as units $\mathrm{mg}^{-1}$ protein. 
Analysis of AsA, GSH, total ascorbate and total glutathione

AsA and DHA were measured according to Hodges et al. (1996). For each sample, DHA was estimated from the difference between total ascorbate and AsA. Total glutathione, GSSG and GSH were measured according to Griffith (1980). For each sample, GSH was estimated from the difference between total glutathione and GSSG.

\section{Measurement of protein concentration}

Protein concentration was measured according to the method of Bradford (1976).

Analysis of $\mathrm{H}_{2} \mathrm{O}_{2}$

$\mathrm{H}_{2} \mathrm{O}_{2}$ content was determined by measuring the absorption of titanium-hydroperoxide as described by Brennan and Frenkel (1977). The amount of $\mathrm{H}_{2} \mathrm{O}_{2}$ was calculated from the standardized $\mathrm{H}_{2} \mathrm{O}_{2}$ curve.

\section{Measurement of malondialdehyde (MDA)content and electrolyte leakage (EL)}

MDA content was measured by thiobarbituric acid (TBA) reaction as described by Hodges et al. (1999). EL was determined according to Zhao et al. (2004). EL was expressed as the relative ion leakage, a percentage of the total conductivity after boiling.

\section{Statistical analysis}

The results presented were the mean of five replicates. Means were compared by one-way analysis of variance and Duncan's multiple range test at the 5\% level of significance.

\section{Results}

Effect of water stress and DPI on $\mathrm{H}_{2} \mathrm{O}_{2}$ content

Water stress led to an increase in $\mathrm{H}_{2} \mathrm{O}_{2}$ content (Fig. 1). Compared to the control, water stress increased $\mathrm{H}_{2} \mathrm{O}_{2}$ content by $147.5 \%$ and $116.2 \%$ after 24 and $48 \mathrm{~h}$ of treatment, respectively. Pre-treatment with DPI markedly inhibited $\mathrm{H}_{2} \mathrm{O}_{2}$ accumulation under water stress. Compared to water stress alone, pre-treatment with DPI decreased $\mathrm{H}_{2} \mathrm{O}_{2}$ content by $63.6 \%$ and $52.9 \%$ after 24 and $48 \mathrm{~h}$ of treatment, respectively. Application of exogenous $\mathrm{H}_{2} \mathrm{O}_{2}$ to DPI-inhibited seedlings increased $\mathrm{H}_{2} \mathrm{O}_{2}$ content under water stress, which indicated that exogenous $\mathrm{H}_{2} \mathrm{O}_{2}$ reversed the effect of DPI on $\mathrm{H}_{2} \mathrm{O}_{2}$ content. These results indicated that water stress induced $\mathrm{H}_{2} \mathrm{O}_{2}$ accumulation and pre-treatment with DPI inhibited $\mathrm{H}_{2} \mathrm{O}_{2}$ accumulation in stressed leaves of wheat. 


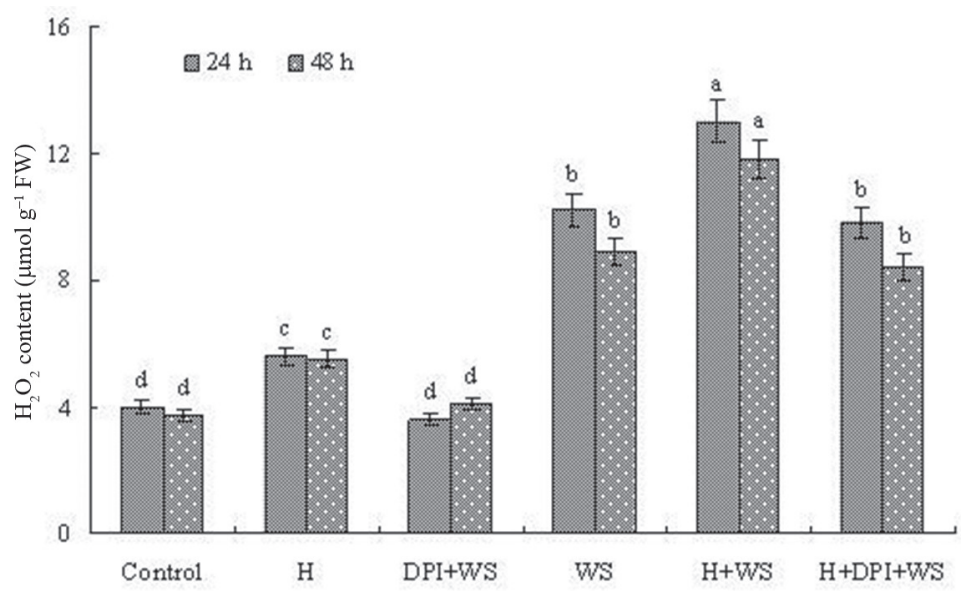

Figure 1. Effects of water stress and DPI on $\mathrm{H}_{2} \mathrm{O}_{2}$ content in leaves of wheat seedlings. The plants were treated as follows: Control, distilled water; $\mathrm{H}, 30 \mu \mathrm{M} \mathrm{H}_{2} \mathrm{O}_{2}$; DPI+WS, $80 \mu \mathrm{M} \mathrm{DPI}+10 \%$ PEG; WS, 10\% PEG; $\mathrm{H}+\mathrm{WS}, 30 \mu \mathrm{M} \mathrm{H}_{2} \mathrm{O}_{2}+10 \%$ PEG; $\mathrm{H}+\mathrm{DPI}+\mathrm{WS}, 30 \mu \mathrm{M} \mathrm{H}_{2} \mathrm{O}_{2}+80 \mu \mathrm{M}$ DPI $+10 \%$ PEG. The plants were pretreated with H, DPI or H+DPI for $12 \mathrm{~h}$ and then exposed to distilled water or water stress for 24 and $48 \mathrm{~h}$. The letters $\mathrm{a}, \mathrm{b}, \mathrm{c}$ and $\mathrm{d}$ mean that there are significant differences between different treatments at the $5 \%$ level of significance

\section{Effects of water stress and DPI on the activities of enzymes in ascorbate and glutathione metabolism}

Table 1 showed that the activities of APX, GR, DHAR, MDHAR, $\gamma$-ECS and GalLDH in ascorbate and glutathione metabolism increased under water stress. Pre-treatment with DPI significantly reduced the activities of APX, GR, DHAR, MDHAR, $\gamma$-ECS and GalLDH in stressed leaves of wheat. Application of exogenous $\mathrm{H}_{2} \mathrm{O}_{2}$ to DPI-inhibited seedlings increased the activities of above enzymes under water stress, which indicated that exogenous $\mathrm{H}_{2} \mathrm{O}_{2}$ reversed the effect of DPI on the activities of above enzymes in stressed leaves. These results suggested that the accumulation of $\mathrm{H}_{2} \mathrm{O}_{2}$ was involved in the regulation of ascorbate and glutathione metabolism under water stress.

\section{Effects of water stress and DPI on the contents of AsA, total ascorbate, GSH, and total glutathione}

Pre-treatment with DPI significantly reduced the contents of AsA, GSH, total ascorbate and total glutathione induced by water stress (Table 2). Application of exogenous $\mathrm{H}_{2} \mathrm{O}_{2}$ to DPI-inhibited seedlings increased the contents of above metabolites under water stress, which indicated that exogenous $\mathrm{H}_{2} \mathrm{O}_{2}$ reversed the effect of DPI on the contents of above metabolites in stressed leaves. These results suggested that the accumulation of $\mathrm{H}_{2} \mathrm{O}_{2}$ under water stress increased the contents of AsA, GSH, total ascorbate and total glutathione. Above results suggested once again that the accumulation of $\mathrm{H}_{2} \mathrm{O}_{2}$ was involved in the regulation of ascorbate and glutathione metabolism under water stress. 
Table 1. Effects of water stress and DPI on the activities of enzymes in ascorbate and glutathione metabolism in leaves of wheat seedlings

\begin{tabular}{|c|c|c|c|c|c|c|c|}
\hline Parameters & $\begin{array}{l}\text { Time } \\
\text { (h) }\end{array}$ & Control & $\mathrm{H}$ & DPI+WS & WS & $\mathrm{H}+\mathrm{WS}$ & $\mathrm{H}+\mathrm{DPI}+\mathrm{WS}$ \\
\hline \multirow{2}{*}{$\begin{array}{l}\mathrm{APX} \\
{\left[\mathrm{U} \mathrm{mg}^{-1} \text { (protein) }\right]}\end{array}$} & 24 & $1.5 \pm 0.18 \mathrm{~d}$ & $2.2 \pm 0.26 \mathrm{c}$ & $1.8 \pm 0.23 \mathrm{~d}$ & $3.3 \pm 0.31 b$ & $4.1 \pm 0.52 \mathrm{a}$ & $3.0 \pm 0.32 b$ \\
\hline & 48 & $1.7 \pm 0.16 \mathrm{~d}$ & $2.0 \pm 0.22 \mathrm{c}$ & $1.7 \pm 0.22 \mathrm{~d}$ & $2.6 \pm 0.25 b$ & $3.3 \pm 0.31 \mathrm{a}$ & $2.3 \pm 0.26 b$ \\
\hline \multirow{2}{*}{$\begin{array}{l}\text { GR } \\
{\left[\mathrm{U} \mathrm{mg}^{-1} \text { (protein) }\right]}\end{array}$} & 24 & $1.2 \pm 0.13 \mathrm{~d}$ & $1.4 \pm 0.12 \mathrm{c}$ & $1.2 \pm 0.15 \mathrm{~d}$ & $1.9 \pm 0.21 b$ & $2.5 \pm 0.28 \mathrm{a}$ & $1.7 \pm 0.21 \mathrm{~b}$ \\
\hline & 48 & $1.0 \pm 0.11 \mathrm{~d}$ & $1.3 \pm 0.16 \mathrm{c}$ & $1.3 \pm 0.18 \mathrm{c}$ & $1.7 \pm 0.21 b$ & $2.3 \pm 0.22 \mathrm{a}$ & $1.6 \pm 0.16 b$ \\
\hline \multirow{2}{*}{$\begin{array}{l}\text { DHAR } \\
{\left[\mathrm{U} \mathrm{mg}^{-1} \text { (protein)] }\right.}\end{array}$} & 24 & $3.1 \pm 0.41 \mathrm{~d}$ & $3.9 \pm 0.44 \mathrm{c}$ & $2.8 \pm 0.28 \mathrm{~d}$ & $5.3 \pm 0.62 b$ & $6.2 \pm 0.55 \mathrm{a}$ & $4.9 \pm 0.55 b$ \\
\hline & 48 & $2.9 \pm 0.31 \mathrm{~d}$ & $3.8 \pm 0.40 \mathrm{c}$ & $3.3 \pm 0.42 \mathrm{~d}$ & $4.4 \pm 0.48 b$ & $5.3 \pm 0.48 \mathrm{a}$ & $4.5 \pm 0.48 b$ \\
\hline \multirow{2}{*}{$\begin{array}{l}\text { MDHAR } \\
{\left[\mathrm{U} \mathrm{mg}^{-1} \text { (protein) }\right]}\end{array}$} & 24 & $1.6 \pm 0.15 d$ & $2.1 \pm 0.20 \mathrm{c}$ & $1.9 \pm 0.19 \mathrm{c}$ & $3.0 \pm 0.33 b$ & $3.8 \pm 0.45 a$ & $2.6 \pm 0.27 b$ \\
\hline & 48 & $1.8 \pm 0.18 \mathrm{~d}$ & $2.2 \pm 0.23 \mathrm{c}$ & $1.5 \pm 0.21 \mathrm{~d}$ & $2.5 \pm 0.25 b$ & $3.6 \pm 0.33 \mathrm{a}$ & $2.8 \pm 0.31 b$ \\
\hline \multirow{2}{*}{$\begin{array}{l}\text { GalLDH } \\
{\left[\mathrm{U} \mathrm{mg}^{-1} \text { (protein) }\right]}\end{array}$} & 24 & $3.2 \pm 0.37 \mathrm{~d}$ & $3.9 \pm 0.46 c$ & $2.8 \pm 0.36 \mathrm{~d}$ & $5.1 \pm 0.56 b$ & $5.9 \pm 0.54 \mathrm{a}$ & $4.6 \pm 0.49 b$ \\
\hline & 48 & $2.9 \pm 0.25 \mathrm{~d}$ & $3.7 \pm 0.33 c$ & $2.9 \pm 0.32 \mathrm{~d}$ & $4.5 \pm 0.47 b$ & $5.6 \pm 0.60 \mathrm{a}$ & $4.9 \pm 0.49 b$ \\
\hline \multirow{2}{*}{$\begin{array}{l}\gamma \text {-ECS } \\
{\left[\mathrm{U} \mathrm{mg}^{-1} \text { (protein) }\right]}\end{array}$} & 24 & $1.7 \pm 0.19 \mathrm{~d}$ & $2.3 \pm 0.32 \mathrm{c}$ & $2.0 \pm 0.22 \mathrm{~d}$ & $3.1 \pm 0.38 b$ & $3.8 \pm 0.43 \mathrm{a}$ & $2.7 \pm 0.33 b$ \\
\hline & 48 & $1.9 \pm 0.24 \mathrm{~d}$ & $2.2 \pm 0.25 \mathrm{c}$ & $1.8 \pm 0.25 \mathrm{~d}$ & $2.8 \pm 0.33 b$ & $3.5 \pm 0.33 \mathrm{a}$ & $2.6 \pm 0.28 b$ \\
\hline
\end{tabular}

Notes: The plants were treated as in Fig. 1. The plants were pretreated with H, DPI or H+DPI for $12 \mathrm{~h}$ and then exposed to distilled water or water stress for 24 and $48 \mathrm{~h}$. The letters a, b, c and d mean that there are significant differences between different treatments at the $5 \%$ level of significance.

Table 2. Effects of water stress and DPI on the contents of AsA, total ascorbate, GSH and total glutathione in leaves of wheat seedlings

\begin{tabular}{|l|c|c|c|c|c|c|c|}
\hline \multicolumn{1}{|c|}{ Parameters } & $\begin{array}{c}\text { Time } \\
(\mathrm{h})\end{array}$ & Control & $\mathrm{H}$ & DPI+WS & WS & H+WS & H+DPI+WS \\
\hline \multirow{2}{*}{$\begin{array}{l}\text { AsA } \\
{\left[\mu \mathrm{mol} \mathrm{g}{ }^{-1}(\mathrm{FW})\right]}\end{array}$} & 24 & $4.10 \pm 0.44 \mathrm{~d}$ & $4.83 \pm 0.53 \mathrm{c}$ & $3.65 \pm 0.40 \mathrm{~d}$ & $7.51 \pm 0.82 \mathrm{~b}$ & $8.64 \pm 0.95 \mathrm{a}$ & $6.97 \pm 0.71 \mathrm{~b}$ \\
\cline { 2 - 8 } & 48 & $4.10 \pm 0.51 \mathrm{~d}$ & $5.17 \pm 0.55 \mathrm{c}$ & $3.83 \pm 0.36 \mathrm{~d}$ & $6.60 \pm 0.73 \mathrm{~b}$ & $7.97 \pm 0.77 \mathrm{a}$ & $7.19 \pm 0.75 \mathrm{~b}$ \\
\hline $\begin{array}{l}\text { Total ascorbate } \\
{[\mu \mathrm{mol} \mathrm{g}}\end{array}$ & 24 & $4.27 \pm 0.41 \mathrm{~d}$ & $5.08 \pm 0.47 \mathrm{c}$ & $4.05 \pm 0.50 \mathrm{~d}$ & $8.34 \pm 0.81 \mathrm{~b}$ & $9.70 \pm 1.11 \mathrm{a}$ & $7.66 \pm 0.84 \mathrm{~b}$ \\
\cline { 2 - 8 } & 48 & $4.36 \pm 0.48 \mathrm{~d}$ & $5.41 \pm 0.62 \mathrm{c}$ & $4.35 \pm 0.45 \mathrm{~d}$ & $7.25 \pm 0.80 \mathrm{~b}$ & $9.06 \pm 0.86 \mathrm{a}$ & $7.98 \pm 0.77 \mathrm{~b}$ \\
\hline $\begin{array}{l}\text { GSH } \\
{\left[\mu \mathrm{mol} \mathrm{g}{ }^{-1}(\mathrm{FW})\right]}\end{array}$ & 24 & $0.23 \pm 0.03 \mathrm{~d}$ & $0.33 \pm 0.03 \mathrm{c}$ & $0.25 \pm 0.04 \mathrm{~d}$ & $0.49 \pm 0.06 \mathrm{~b}$ & $0.60 \pm 0.07 \mathrm{a}$ & $0.44 \pm 0.05 \mathrm{~b}$ \\
\cline { 2 - 8 } & 48 & $0.26 \pm 0.04 \mathrm{~d}$ & $0.37 \pm 0.04 \mathrm{c}$ & $0.27 \pm 0.03 \mathrm{~d}$ & $0.43 \pm 0.04 \mathrm{~b}$ & $0.56 \pm 0.06 \mathrm{a}$ & $0.46 \pm 0.06 \mathrm{~b}$ \\
\hline $\begin{array}{l}\text { Total glutathione } \\
{[\mu \mathrm{mmol} \mathrm{g}-1(\mathrm{FW})]}\end{array}$ & 24 & $0.27 \pm 0.04 \mathrm{~d}$ & $0.38 \pm 0.04 \mathrm{c}$ & $0.30 \pm 0.04 \mathrm{~d}$ & $0.54 \pm 0.06 \mathrm{~b}$ & $0.66 \pm 0.08 \mathrm{a}$ & $0.50 \pm 0.08 \mathrm{~b}$ \\
\cline { 2 - 8 } & 48 & $0.31 \pm 0.06 \mathrm{~d}$ & $0.43 \pm 0.05 \mathrm{c}$ & $0.34 \pm 0.05 \mathrm{~d}$ & $0.48 \pm 0.07 \mathrm{~b}$ & $0.63 \pm 0.05 \mathrm{a}$ & $0.53 \pm 0.08 \mathrm{~b}$ \\
\hline
\end{tabular}

Notes: The plants were treated as in Fig. 1. The plants were pretreated with $\mathrm{H}$, DPI or $\mathrm{H}+\mathrm{DPI}$ for $12 \mathrm{~h}$ and then exposed to distilled water or water stress for 24 and $48 \mathrm{~h}$. The letters a, b, c and d mean that there are significant differences between different treatments at the $5 \%$ level of significance.

\section{Effects of water stress and DPI on MDA content and EL}

Pre-treatment with DPI significantly increased MDA content and EL of stressed leaves (Fig. 2). Application of exogenous $\mathrm{H}_{2} \mathrm{O}_{2}$ to DPI-inhibited seedlings decreased MDA content and EL of stressed leaves, which indicated that exogenous $\mathrm{H}_{2} \mathrm{O}_{2}$ reversed the effect 

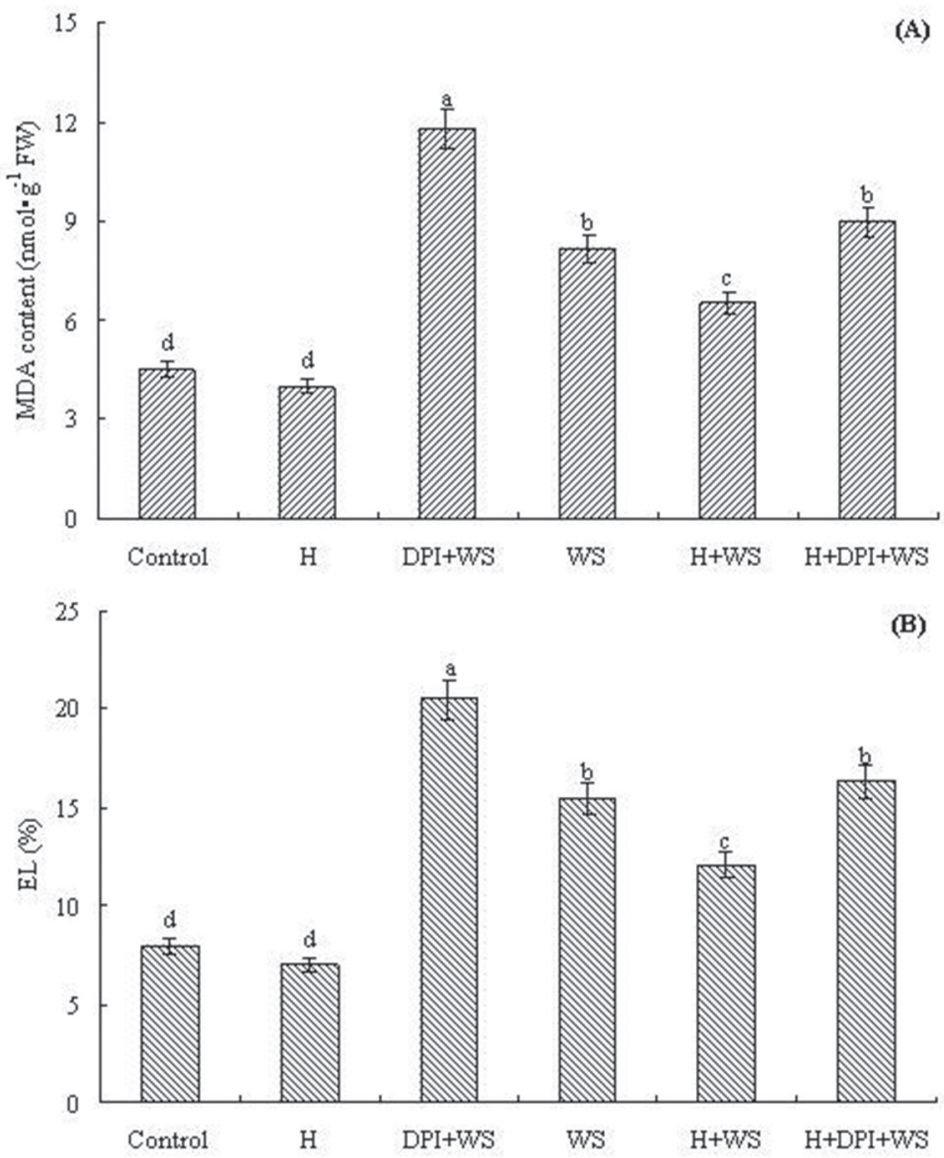

Figure 2. Effects of water stress and DPI on MDA content (A) and EL (B) of wheat leaves. The plants were treated as Fig. 1. The plants were pretreated with H, DPI or H+DPI for $12 \mathrm{~h}$ and then exposed to distilled water or water stress for $48 \mathrm{~h}$.

of DPI on MDA content and EL of stressed leaves in stressed leaves. These results suggested that $\mathrm{H}_{2} \mathrm{O}_{2}$ has important role for acquisition of water stress tolerance in wheat.

\section{Discussion}

AsA is an important compound of plant antioxidant system and a major redox compound in plants, which can be regulated by enzymes in its recycling pathway and biosynthesis. Jiang and Zhang (2002a, b) reported that water stress-induced $\mathrm{H}_{2} \mathrm{O}_{2}$ increased the accumulation of AsA and APX activity. Our present study showed that water stress-induced $\mathrm{H}_{2} \mathrm{O}_{2}$ also increased AsA content and APX activity, which was consistent with previous study. Besides, our study also indicated that water stress-induced $\mathrm{H}_{2} \mathrm{O}_{2}$ increased the ac- 
tivities of the recycling enzymes DHAR and MDHAR and biosynthetic enzyme GalLDH, and total ascorbate. These results indicated that water stress-induced $\mathrm{H}_{2} \mathrm{O}_{2}$ could regulate AsA content through APX, DHAR, MDHAR and GalLDH.

GSH is another important compound of plant antioxidant system. The cellular content of GSH can be determined by $\gamma$-ECS and GR, which are the key enzymes in its biosynthetic and recycling pathway, respectively. It has been reported that $\mathrm{H}_{2} \mathrm{O}_{2}$ increased GSH accumulation and GR activity in the leaves of maize and cucumber under water stress (Jiang and Zhang 2002b; Liu et al. 2009). Our results also showed that $\mathrm{H}_{2} \mathrm{O}_{2}$ increased GR activity and GSH content under water stress, which was consistent with previous study. Besides, our study also indicated that $\mathrm{H}_{2} \mathrm{O}_{2}$ accumulation increased $\gamma$-ECS activity and total glutathione content under water stress. Above results indicated that water stress-induced $\mathrm{H}_{2} \mathrm{O}_{2}$ regulated the contents of GSH and total glutathione through GR and $\gamma$-ECS.

Besides, our findings showed that the 12-h long hydrogen-peroxide pre-treatment alone had altered only the measured internal hydrogen-peroxide content significantly, there were no effect on the MDA level and the electrolyte leakage. This can be explained by the significant increase in the activity of the protective ascorbate-glutathione cycle enzymes and in the levels of ascorbic acid and reduced glutathione.

Plant hormones abscisic acid (ABA) and jasmonic acid (JA) increased under water stress (Shan and Liang 2010; Xing et al. 2016). As stress signals, they have important roles in defencing oxidative stress (Alavi-Samani et al. 2015; Guajardo et al. 2016). Jiang and Zhang (2002b) reported that water stress-induced $\mathrm{H}_{2} \mathrm{O}_{2}$ increased the accumulation os AsA and APX activity. It has been reported that $\mathrm{H}_{2} \mathrm{O}_{2}$ increased GSH accumulation and GR activity in the leaves of maize and cucumber under water stress (Jiang and Zhang 2002b; Liu et al. 2009). Plant hormones abscisic acid (ABA) and jasmonic acid (JA) increased under water stress (Shan and Liang 2010; Xing et al. 2016). As stress signals, they have important roles in defencing oxidative stress (Alavi-Samani et al. 2015; Guajardo et al. 2016). Jiang and Zhang (2002b) reported that $\mathrm{H}_{2} \mathrm{O}_{2}$ was involved in ABA signaling in the regulation of ascorbate-glutathione cycle through APX and GR under water stress. However, whether $\mathrm{H}_{2} \mathrm{O}_{2}$ is involved in ABA signaling in the regulation of AsA-GSH cycle through DHAR and MDHAR, and the biosynthesis of ascorbate and glutathione through GalLDH and $\gamma$-ECS remains unknown. Our previous study showed that JA regulated ascorbate and glutathione metabolism in A. cristatum leaves under water stress (Shan and Liang 2010). Besides, Dai et al. (2015) reported that JA-induced $\mathrm{H}_{2} \mathrm{O}_{2}$ regulated ascorbate and glutathione metabolism through AsA-GSH cycle and their biosynthesis. If ABA had the same effect as JA in regulating ascorbate and glutathione metabolism, it is also very interesting to investigate the relationship between ABA and JA in regulating AsA-GSH cycle and the biosynthesis of ascorbate and glutathione. This part work will provide more new knowledge to the antioxidant metabolism in wheat crop under water stress.

In conclusion, our results clearly suggest that water stress-induced $\mathrm{H}_{2} \mathrm{O}_{2}$ accumulation participates in the regulation of ascorbate and glutathione metabolism by increasing the activities of APX, GR, MDHAR, DHAR, GalLDH, $\gamma$-ECS and the contents of AsA, GSH, 
total ascorbate and total glutathione, which, in turn, protects wheat crop against water stress. These results provide new knowledge to the antioxidant metabolism in wheat crop under water stress.

\section{Acknowledgements}

Our study was funded by "Open project of Crop Science Characteristic Discipline of Henan Province" and "Important Science and Technology Specific Project of Henan Province (151100110700)".

\section{References}

Alavi-Samani, S.M., Kachouei, M.A., Pirbalouti, A.G. 2015. Growth, yield, chemical composition, and antioxidant activity of essential oils from two thyme species under foliar application of jasmonic acid and water deficit conditions. Hortic. Environ. Biotechnol. 56:411-420.

Andriunas, F.A., Zhang, H.M., Xia, X., Offler, C.E., McCurdy, D.W., Patrick, J.W. 2012. Reactive oxygen species form part of a regulatory pathway initiating trans-differentiation of epidermal transfer cells in Vicia faba cotyledons. J. Exp. Bot. 63:3617-3629.

Ansari, W.A., Atri, N., Singh, B., Pandey, S. 2016. Changes in antioxidant enzyme activities and gene expression in two muskmelon genotypes under progressive water stress. Biol. Plant. 61:333-341.

Bradford, M.M. 1976. A rapid and sensitive method for the quantitation of microgram quantities of protein utilizing the principle of protein-dye binding. Anal. Biochem. 72:248-254.

Brennan, T., Frenkel, C. 1977. Involvement of hydrogen peroxide in the regulation of senescence in pear. Plant Physiol. 59:411-416.

Dai, H., Jia, G., Shan, C. 2015. Jasmonic acid-induced hydrogen peroxide activates MEK1/2 in upregulating the redox states of ascorbate and glutathione in wheat leaves. Acta Physiol. Plant. 37:200.

Dalton, D.A., Russell, S.A., Hanus, F.J., Pascoe, G.A., Evans, H.J. 1986. Enzymatic reactions of ascorbate and glutathione that prevent peroxide damage in soybean root nodules. Proc. Natl Acad. Sci. USA 83:38113815 .

Dringen, R. 2000. Glutathione metabolism and oxidative stress in neurodegeneration. Eur. J. Biochem. 267:4903.

Grace, S.C., Logan, B.A. 1996. Acclimation of foliar antioxidant systems to growth irradiance in three broadleaved evergreen species. Plant Physiol. 112:1631-1640.

Griffith, O.W. 1980. Determination of glutathione and glutathione disulfide using glutathione reductase and 2-vinylpyridine. Anal. Biochem. 106:207-212.

Guajardo, E., Correa, J.A., Contreras-Porcia, L. 2016. Role of abscisic acid (ABA) in activating antioxidant tolerance responses to desiccation stress in intertidal seaweed species. Planta 243:767-781.

Hodges, D.M., Andrews, C.J., Johnson, D.A., Hamilton, R.I. 1996. Antioxidant compound responses to chilling stress in differentially sensitive inbred maize lines. Plant Physiol. 98:685-692.

Hodges, M.D., DeLong, J.M., Forney, C.F., Prange, R.K. 1999. Improving the thiobarbituric acid-reactivesubstances assay for estimating lipid peroxidation in plant tissues containing anthocyanin and other interfering compounds. Planta 207:604-611.

Jiang, M.Y., Zhang, J.H. 2002a. Role of abscisic acid in water stress-induced antioxidant defense in leaves of maize seedlings. Free Rad. Res. 36:1001-1015.

Jiang, M.Y., Zhang, J.H. 2002b. Water stress-induced abscisic acid accumulation triggers the increased generation of reactive oxygen species and up-regulates the activities of antioxidant enzymes in maize leaves. J. Exp. Bot. 53:2401-2410. 
Liu, Z.J., Guo, Y.K., Lin, S.H., Bai, J.G. 2009. Effects of exogenous hydrogen peroxide on ultra structure of chloroplasts and activities of antioxidant enzymes in greenhouse-ecotype cucumber under drought stress. Acta Horti. Sin. 36:1140-1146.

Miyake, C., Asada, K. 1992. Thylakoid-bound ascorbate peroxidase in spinach chloroplasts and photoreduction of its primary oxidation product monodehydroascorbate radicals in thylakoids. Plant Cell Physiol. 33:541553.

Mohammadi, H., Moradi, F. 2016. Effects of growth regulators on enzymatic and non-enzymatic antioxidants in leaves of two contrasting wheat cultivars under water stress. Braz. J. Bot. 39:495-505.

Mostofa, M.G., Fujita, M., Tran, L.S.P. 2015. Nitric oxide mediates hydrogen peroxide- and salicylic acidinduced salt tolerance in rice (Oryza sativa L.) seedlings. Plant Growth Regul. 77:265-277.

Nakano, Y., Asada, K. 1981. Hydrogen peroxide is scavenged by ascorbate specific peroxidase in spinach chloroplasts. Plant Cell Physiol. 22:867-880.

Rüegsegger, A., Brunold, C. 1992. Effect of cadmium on $\gamma$-glutamylcysteine synthesis in maize seedlings. Plant Physiol. 99:428-433.

Sang, Q.Q., Shu, S., Shan, X., Guo, S.R. 2016. Effects of exogenous spermidine on antioxidant system of tomato seedlings exposed to high temperature stress. Russ. J. Plant Physiol. 63:645-655.

Shan, C., Liang, Z. 2010. Jasmonic acid regulates ascorbate and glutathione metabolism in Agropyron cristatum leaves under water stress. Plant Sci. 178:130-139.

Singh, V.P., Singh, S., Kumar, J., Prasad, S.M. 2015. Investigating the roles of ascorbate-glutathione cycle and thiol metabolism in arsenate tolerance in ridged Luffa seedlings. Protoplasma 252:1217-1229.

Tabata, K., Oba, K., Suzuki, K., Esaka, M. 2001. Generation and properties of ascorbic acid-deficient transgenic tobacco cells expressing antisense RNA of L-galactono-1,4-lactone dehydrogenase. Plant J. 27:139148 .

Wang, Y., Zhang, J., Li, J.L., Ma, X. 2014. Exogenous hydrogen peroxide enhanced the thermotolerance of Festuca arundinacea and Lolium perenne by increasing the antioxidative capacity. Acta Physiol. Plant. 36:2915-2924.

Wheeler, G.L., Jones, M.A., Smirnoff, N. 1998. The biosynthetic pathway of vitamin C in higher plants. Nature 393:365-369.

Wu, Z., Zhang, C., Yan, J., Yue, Q., Ge, Y. 2015. Effects of sulfur supply and hydrogen peroxide pretreatment on the responses by rice under cadmium stress. Plant Growth Regul. 77:299-306.

Xing, X., Zhou, Q., Xing, H., Jiang, H., Wang, S. 2016. Early abscisic acid accumulation regulates ascorbate and glutathione metabolism in soybean leaves under progressive water stress. J. Plant Growth Regul. 35:865-876.

Zhang, A., Jiang, M., Zhang, J., Ding, H., Xu, S., Hu, X., Tan, M. 2007. Nitric oxide induced by hydrogen peroxide mediates abscisic acid-induced activation of the mitogen-activated protein kinase cascade involved in antioxidant defense in maize leaves. New Phytol. 175:36-50.

Zhao, L.Q., Zhang, F., Guo, J.K., Yang, Y.L., Li, B.B., Zhang, L.X. 2004. Nitric oxide functions as a signal in salt resistance in the calluses from two ecotypes of reed. Plant Physiol. 134:849-857. 